\title{
PUBLIC GOVERNANCE QUALITY AND INCOME TAX NON-COMPLIANCE AMONG SMALL AND MEDIUM ENTERPRISES IN YEMEN
}

\author{
Lutfi Hassen Ali Al-Ttaffi ${ }^{1}$ and Hijattulah Abdul-Jabbar ${ }^{2}$ \\ ${ }^{1}$ Faculty of Administrative Science, Seiyun University, Yemen \\ E-mail: alttaffilutfi@yahoo.com \\ ${ }^{2}$ Tunku Puteri Intan Safinaz School of Accountancy, \\ Universiti Utara Malaysia, Malaysia \\ E-mail: hijat@uum.edu.my
}

\begin{abstract}
The problem of tax non-compliance is broadly recognized as a serious phenomenon in many countries, especially in the Middle East countries in general and Yemen in particular. However, there is a lack of studies that provide causal explanations of this issue in these countries. Previous studies indicate a number of factors that could possibly influence tax compliance behaviour. In this regard, this study was undertaken primarily to examine the relationship between taxpayers' perception among SMEs in Yemen about the quality of public governance and their non-compliant behaviour in order to have better understanding of non-compliant behaviour. For the purpose of data collection, a questionnaire was designed and utilized in this study. The analysis reveals that public governance quality is perceived as low in Yemen. A simple regression analysis found that public governance quality has a significant negative influence on tax non-compliant behaviour. Consequently, this study recommends the Yemeni government improves the level of the quality of public governance in order to enhance the level of tax compliance among Yemeni taxpayers.
\end{abstract}

Keywords: tax non-compliance, public governance quality, Yemen, SMEs

ARTICLE INFO

Article History:

Received: 1 December 2019

Accepted: 30 June 2020

Published: 31 August 2020 


\section{INTRODUCTION}

The economy of many countries around the world is essentially based on tax revenue as a main source. However, this source is always faced by the challenge of non-compliance among taxpayers. Mas'ud, Aliyu, and Gambo (2014) explained that the level of tax noncompliance in developing countries is much more than that of developed countries. Generally, tax non-compliance is a problem that dates back to the earliest recorded history of humanity (Hallsworth, List, Metcalfe, \& Vlaev, 2017). Arguably, the phenomenon of tax non-compliance is being viewed as a threat to the economy of many countries (Ross \& McGee, 2012). The Middle Eastern region is an important area that has contributed to the growth of the global economy (Carapico, 1998). Middle Eastern countries are mostly classified as developing countries and have recorded high level of tax non-compliance (Yemen Times, 2005). Nevertheless, it is evident that there is a lack of tax compliance studies in this region (Aljaaidi, Manaf, \& Karlinsky, 2011; Helhel \& Ahmed, 2014).

Yemen, as a Middle Eastern country, is categorized as a least developing country that suffers a continuous high level of financial corruption including tax non-compliance (World Bank, 2018). However, the literature has shown that there a lack of studies on tax compliance and non-compliance. During the period from 2000 to 2010, Yemen regulated new tax laws and reforms in order to overcome the weaknesses in the tax system, but the volume of tax non-compliance is still questionable (Aljaaidi, Manaf, \& Karlinsky, 2011; Al-Ttaffi, Manaf, Aljaidi, \& McGee, 2011; Helhel \& Ahmed, 2014).

The current study investigated the determinants of income tax noncompliance behaviour among SMEs in Yemen. Particularly, the present paper reports findings from an important part of the study, which relates specifically to the issue of public governance quality, as one of the key factors that have had an influence on tax non-compliance behaviour. The next section explains the problem statement of the research and provides the reasons that motivated the researchers to conduct this study. The literature review is presented in the third part, which highlights the studies on tax non-compliance and studies related to public governance quality and its relationship with the issue of tax non-compliance. In the fourth section, the research methodology and data collection methods are described. The result 
of data analysis are presented and discussed in the fifth section, and finally the conclusion and implications of the study re explained in the sixth section.

\section{STATEMENT OF THE PROBLEM}

In Yemen, as many other developing countries, tax non-compliance is considered to be a serious challenge facing tax authorities and preventing tax revenue performance. The tax authority in Yemen has regulated many reforms from 1990 to 2010 to overcome the weaknesses in the tax system. Nevertheless, data shows that the amount of tax non-compliance is on an increasing trend and remains a serious concern (United Nations Development Program [UNDP], 2005; Ministry of Planning and International Cooperation [MPIC], 2009; Al-Batly, 2014; Central Organization of Control and Audit [COCA],2015), and also has led Yemen into a serious financial problem (MPIC, 2014). Specifically, in 2004 the amount of non-compliance was USD164 million, and increased to USD2billion and USD2.5billion respectively in 2009 and 2012, and further increased to USD3 billion and USD4 billion in 2013 and 2014 respectively (Ministry of Planning \& International Cooperation [MPIC], 2014; Al-Saadi, 2014; COCA, 2015). A Yemeni economic expert Abdul Majid Al-Batly (2014) explained that the Yemeni budget suffers a sharp deficit; therefore, diversifying sources of public revenue is required to cover this deficit. One of the most important sources of the government budget is tax revenue, but it is still at a low level of contribution to the Gross Domestic Product (GDP).

According to the Yemeni News Agency (2012), the Yemeni cabinet approved a budget for 2013, with a deficit of 690 billion Yemeni Reals (YR) (USD3.2 billion). By comparing the amount of tax non-compliance for the year 2013 (USD3 billion) with the deficit in the budget for the same year (USD3.2 billion), it could be noted that the phenomenon of tax noncompliance in Yemen was an obstacle to the government to cover the deficit in their budgets, and thus the government remains in need of international and regional aids, as this would lead to the collapse of the nation in the event of an interruption of such assistance. Therefore, addressing the issue of tax non-compliance is crucial to finance the budget and reduce the deficit. 
The current study focused on the Small and Medium Enterprises (SMEs). Due to its characteristics, it is common for the owners-managers of SMEs to have the tendency not to comply with tax rules (Mohamad, Zakaria, \& Hamid, 2016), since they have higher opportunities to be involved in cash business transactions (Radzi \& Ariffin, 2018). In Yemen, the economy relies heavily on the SME sector, which represent $99.6 \%$ of business enterprises in Yemen (MPIC, 2014; Central Organization of Statistic [COS], 2013). Moreover, the number of SMEs is increasing, as it was about 32,649 in 1996, and in 2000 the number is 33,351 , to reach in 2004 to more than 41,000 and 45,483 in 2010 (COS, 2013; National Information System [NIS], 2012; Ministry of Industry \& Trade [MIT], 2012). However, the tax revenue from this sector is considered to be extremely low, as it does not represent more than 5\% of tax collection (Al-Saqqaf, 2005; Huda, 2005; Abdulasiz, 2008). The low tax collection from SMEs is likely due to very high non-compliance among SMEs in Yemen. For example, Gubran (2009) indicated that $60 \%$ of SMEs in Sana'a do not comply with tax laws at all, with the remaining $40 \%$ of SMEs displaying some sort of non-compliance offences.

Based on the Social Exchange Theory, relationships between government and citizens are created by the use of subjective cost and benefit, and evolve on the principle of give and take. So, it is expected that the government will equally keep its part of the contract by providing quality public governance. Public governance quality is considered a sensitive issue and this has led researchers to avoid studying this issue up until the recent past. However, research has been carried out in the current decades to examine the impact of public governance quality on tax non-compliance (Ser, 2013). This study contributes to the Yemeni tax context by investigating the relationship between the quality of public governance in Yemen and the likely non-compliance of Yemeni taxpayers.

\section{LITERATURE REVIEW}

\section{Tax Non-Compliance Studies}

Many studies conducted about tax compliance focused on the classic model of tax compliance, which views the phenomenon mainly from an economic perspective (Gupta \& McGee, 2010), and to some extent the social 
(Jackson \& Millron, 1986; Fischer, Wartick, \& Mark, 1992), cultural (Yong \& Martin, 2016) and legal (Klepper, Mazur, \& Nagin, 1991) perspectives as well. Thus, it could be argued that there is a lack of literature on the effect of social psychological factors on tax non-compliance.

Ross and McGee (2012) cited that in 1944, Crowe proposed a wide study on the ethics of tax non-compliance from the philosophical and religious aspects, and found that there are three ethical aspects, particularly, never ethical, always ethical or ethical under certain facts and circumstances. The reviews of Jackson and Milliron (1986) and Richardson and Sawyer (2001) are considered among the comprehensive studies on tax compliance and non-compliance. Jackson and Milliron (1986) summarized 14 variables that may influence tax non-compliance, namely: age, gender, education, income level, income source, occupation, peer influence, ethics, fairness, complexity, IRS contact, probability of being detected, penalties and tax rates. Richardson and Sawyer (2001) provided an extensive review of more than 130 studies on tax compliance published from 1985 to 1997. The two articles of Jackson and Milliron (1986) and Richardson and Sawyer (2001) presented the most important variables, methods, issues and theories of tax compliance (Abdul-Jabbar \& Pope, 2008). Furthermore, numerous studies have been carried out to explore the issue of tax non-compliance globally, covering South America, North America, Asia, Europe, Australia and New Zealand (for instance: McGee, 2006; McGee, Benk, Ross, \& Kılıçaslan, 2012; McGee, Petrides, \& Ross, 2012; Al-Ttaffi \& Abdul-Jabbar, 2016; Nwidobie, 2018; Almunia \& Lopez-Rodriguez, 2018; Nagel, Huber, Van Praag, \& Goslinga, 2019). However, the Middle Eastern region is not focused sufficiently.

In investigating the causes of tax non-compliance in Yemen, the researchers noted the lack of research in the area. In other words, no many studies have been conducted in the Middle Eastern region as a whole, and Yemen in particular, with respect to perception of taxpayers towards tax compliance (Al-Ttaffi et al., 2011). However, few studies have offered possible explanations on why Yemenis are not complying with tax laws as well as factors influencing their taxpaying behaviour.

Al-Doais (2008) conducted a descriptive study on the role of accounting information systems (AIS) in reducing tax evasion in the 
Republic of Yemen. In his study, AIS was described as an effective factor that could possibly be a useful tool to reduce the amount of tax non-compliance. Gubran (2009) found that the unfairness of the government is the main reason of tax non-compliance in Yemen. Aljaaidi et al. (2011) presented a study to find out the perception of Yemenis towards tax evasion whether it is considered to be a crime or not. It was found the Yemeni people do not perceive tax evasion as a crime. Helhel and Ahmed (2014) classified the tax non-compliance in Yemen into 2 groups, namely, internal factors and external factors. One of their findings is that the political factor has a positive influence on tax non-compliance. The current study improved this variable by integrating politics with the geographical factor. More recently, Al-Ttaffi and Abdul-Jabbar (2015) proposed a conceptual framework to be applicable in Yemen, and integrated the Islamic religious perspective in the tax non-compliance model. Also, Al-Ttaffi and Abdul-Jabbar (2018) found that the relationship between tax service quality and tax non-compliance behaviour is significant. Aziz and Al-Harethi (2018) reported that the relationship between autonomy, transparency, accountability and motivation with the efficiency of tax administration is significant. In conclusion, the literature showed that the relationship between public governance quality and tax non-compliance has not been investigated so far.

\section{Public Governance Quality}

The literature identifies three types of governance (1) public governance, which is concerned with the government and how to organize the affairs and manage resources, (2) economic governance, which is concerned with the private sector, and (3) social governance, which is concerned with the civil society and non-profit sector. It was pointed out that the attention is always on public governance (United Nations [UN], 2007).

Torgler, Schaffner, and Macintyre (2007) explained that public governance quality is a multidimensional variable. Therefore, they adapted the following dimensions to measure public governance quality:

1. Voice, democracy and accountability: This dimension measures the level of citizens' participation in the selection of the government. Moreover, it measures the financial management of the government in terms of transparency (Kaufmann, Kraay, \& Mastruzzi, 2007; Darby, Desbordes, \& Wooton, 2010). 
2. Government effectiveness: This dimension measures the perceptions of taxpayers about the quality of service provided by the government by measuring the public bureaucracy, the competence of public sector employees, the independence of the civil action from political interference and the extent of the government's commitment to achieve its policies and plans means (Kaufmann et al., 2007; Darby et al., 2010).

3. Rule of law: This dimension measures the level of taxpayers' confidence in the rule of law on society and the degree of the government's commitment to the laws and rules (Kaufmann et al., 2007; Darby et al., 2010).

4. Control of corruption: It is defined as "the exercise of entrusted public power for private gain" (Kaufmann et al., 2007). This dimension measures the perception of the taxpayers about corruption in the public sector (Darby et al., 2010).

In a related study, Newman (2005) linked between the political side and the public governance. He explained that in most countries, the appointment of the head of the tax authority is performed by the key politicians in power in the country, and thus creating a relationship between tax non-compliance and political side through enabling politicians in ruling party indirectly affect the behaviour of tax authorities by enforcing tax authorities to conduct tax assessments in accordance with their own interests.

Also, Torgler et al. (2007) pointed out that the citizens, in order to comply with the tax laws, must participate in the financial decision-making, and the government must be away from the centralization of financial decisions. Kaufmann et al. (2007) cited from some of the World Bank reports that the concept of participation by individuals must be comprehensive by using political methods such as, democracy. Moreover, the government's ability to manage the country's resources effectively and harness all the political tools for the benefit of citizens with respect for the citizens will result in the interaction between government and citizens in the economic, social and political aspects. 
Along the same line of argument, Ser (2013) supposed that if individuals perceive the government to be fair, then they will have more confidence towards the government, and will comply with tax. Damayanti, Sutrisno, Subekti, and Baridwan (2015) supported this opinion. They argued that the perception about the government is the main cause of the intention to comply with tax rules. An instance was given that throughout the period of 1973 - 1994, the U.S. government evidenced that the increase in unreported income is related to the distrust in government.

In a similar take on the relationship, Besancon (2003) extended the duties of the government and suggested that the government exists for the purpose of offering common and political goods to the citizens and further stated that quality of public governance is achieved when the government provides a high quality provision to the individuals. This view was supported by Rotberg (2005), who argued that public governance can be attained when the government supplies common and political goods to the citizens. Furthermore, it was stated that the public governance should be capable of providing satisfaction and material prosperity to citizens. Generally, public governance is judged as "good" when the government uses and manages the resources of the country to respond to the requirements of the citizens. These requirements vary in importance, as some of them are more important than others, so the government should know their priorities.

In general, the relationship between taxpayers and the government is based on the law of reciprocation in psychology, which calls for cooperation from both parties. Many researchers have concluded that public governance quality is negatively correlated to non-compliance (Obid, 2008; Kirchgassner, 2011; Ross \& McGee, 2011). Phillips and Sandall (2009) explained the link between public governance quality and tax noncompliance. They argued that the citizens support the government to do its duties through payment of tax and as such, taxpayers remain interested in the way in which the government uses these mandatory funds.

Furthermore, Lassen (2003) clarified that the political goods offered by the government should deserve the payment of taxpayers. So, based on the concept of quid pro quo, taxpayers will comply with tax laws if they found that the government provides sufficient political goods. 
Besancon (2003) explained that the association between the ruler and the ruled is considered a social contract and as such, the ruler (government) should deliver the political goods, effectively, to attain positive reaction from the ruled (citizens). Torgler (2003) stated that the positive behaviour by the government will generate a positive attitude and action by the citizens to comply with the payment of tax. This viewpoint was supported by the study of Akpo (2009), which reported that good governance required the provision of quality public goods, and that where the government fails to provide public services to the citizens, they will stop paying tax.

Finally, it is worth to highlight that governments finance significant part of their payments from tax revenues and thus, tax compliance is very important as governments could use these funds to provide public service and aid its financial emergency (Ser, 2013). For instance, in Yemen, the amount of tax non-compliance in the year 2013 is approximately equal to the budget deficit for the same year. Hence, eliminating the problem of tax non-compliance will largely support the government to cover such deficit.

\section{METHODOLOGY}

\section{Procedures of Data Collection}

A survey research design was employed to collect the data for the present study. The target population for this study comprised of ownersmanagers of Small and Medium Enterprises in Yemen. According to Zikmund (2003), stratified sampling means selection of a representative sample of sub-groups in the same proportion in the population. Zikmund explained that this technique is useful in ensuring that the sample accurately reflects the population. Sekaran (2003) explained that in stratified sampling, the subjects drawn from each stratum can be either proportionate or disproportionate to the number of elements in the stratum. A quota sampling is a form of proportionate stratified sampling, in which a predetermined proportion is sampled from different groups (Sekaran \& Bougie, 2010). Therefore, a quota sampling technique was used to select the sample of the present study in order to achieve an accurate representativeness of the population of the study. 
The number of SMEs in Yemen is 45,483 in 2010 (COS, 2013). The current study focused on the major seven Yemeni cities that contain a large number of thriving SMEs, namely, Sana'a, Aden, Taiz, Ibb, Hodaidah, Mukalla, and Seiyun. After determining the population (45,483), the seven major Yemeni cities were defined as stratums. As 78.4\% of SMEs in Yemen are located in the major seven cities (MIT, 2011), therefore, the number of SMEs in each city was identified based on the proportions of SMEs in each city. Finally, the quota of each city in the sample was determined in order to define the number of subjects in each city. The data was collected over a two month period from March 2016 to April 2016. Research assistants were used to distribute 500 questionnaires. Out of these questionnaires, 339 usable questionnaires were returned at a response rate of $66 \%$.

\section{Measurement of Variables}

Public governance quality was measured with 17 items and rated using a five-point Likert scale. Respondents were asked to indicate their disagreement or agreement to statements relating to the quality of public governance. The high score " 5 " (strongly agree) indicated that the respondents believed that the quality of public governance is high, whereas a low score "1" (strongly disagree) means low quality. The measuring 17 items were combined to obtain a total scale of public governance quality. The mean score was used for the analysis, and following the $50^{\text {th }}$ percentile method, a mean score of 3 and higher indicated a high perception about public governance quality, while a mean score lower than 3 is an indication of low perception about public governance quality. Tax noncompliance behaviour, was measured with four components covering the four types of income tax compliance/non-compliance situations using an indirect hypothetical scenario case. Respondents were asked to indicate; (i) the amount of income that should be reported on the tax return, (ii) the amount of deduction that should be claimed on the tax return, (iii) the date the income tax returns should be filed, and (iv) how many days after receiving an assessment notice the income tax should be paid. The values were coded as compliance and noncompliance. The overall value of all four types of compliance/non-compliance situations was interpreted as fully compliant, partly compliant and fully noncompliant. 


\section{FINDINGS AND DISCUSSION}

\section{Respondent's Profile}

Descriptive analysis was utilized to explain the respondents profile in terms of 2 main groups of characteristics, namely, demographic information of respondents and business information. Demographic information of respondents included age, gender, marital status and education. Table 1 shows the summary of demographic characteristics of the respondents.

Table 1: Summary of the Respondents' Demographic Characteristics

\begin{tabular}{llcc}
\hline \multicolumn{1}{c}{ Variables } & \multicolumn{1}{c}{ Categories } & Frequencies & Percentages \\
\hline \multirow{3}{*}{ Age (years) } & Less than 30 & 33 & $10 \%$ \\
& $30-50$ & 172 & $52 \%$ \\
& More than 50 & 125 & $38 \%$ \\
\hline \multirow{2}{*}{ Gender } & Male & 311 & $94 \%$ \\
& Female & 19 & $6 \%$ \\
\hline \multirow{3}{*}{ Marital status } & Single & 26 & $8 \%$ \\
& Married & 281 & $85 \%$ \\
& Others & 23 & $7 \%$ \\
\multirow{2}{*}{ Education } & Primary school or less & 74 & $22 \%$ \\
& Secondary school / Diploma & 144 & $44 \%$ \\
& Bachelor degree and above & 112 & $34 \%$ \\
\hline
\end{tabular}

As in the Table above, it is shown that the majority of respondents were between the ages of $30-50$ years (52\%), while $38 \%$ of the respondents were more than 50 years and $10 \%$ were less than 30 years. The summary also shows that the most of respondents were males (94\%), compared to only $6 \%$ females. As for marital status of the respondents, the summary shows that most of the respondents were married (85\%), while $8 \%$ were single and $7 \%$ had other status (such as divorcees and widows). In respect of the education level of the respondents, $44 \%$ of the respondents had secondary school or a diploma level education, followed by $34 \%$ that had a bachelor's degree or above and $22 \%$ of the respondents only went to primary school or less.

Concerning the information of business, it describes the period of business, business sector and location of business. Table 2 shows a summary of business characteristics of the respondents. 
Table 2: Summary of the Respondents' Business Characteristics

\begin{tabular}{clcc}
\hline \multicolumn{1}{c}{ Variables } & \multicolumn{1}{c}{ Categories } & Frequencies & Percentages \\
\hline \multirow{3}{*}{ Period of business (years) } & Less than & 46 & $14 \%$ \\
& $5-10$ & 118 & $36 \%$ \\
& $11-15$ & 110 & $33 \%$ \\
& More than 15 & 56 & $17 \%$ \\
\hline \multirow{3}{*}{ Business sector } & Retail trade & 140 & $42 \%$ \\
& Wholesale trade & 92 & $28 \%$ \\
& Service & 44 & $13 \%$ \\
& Farmer & 21 & $6 \%$ \\
& Industry sector & 12 & $13 \%$ \\
& Livestock & 10 & $3 \%$ \\
& Others & 11 & $4 \%$ \\
\hline \multirow{2}{*}{ Location of business } & North & 194 & $59 \%$ \\
& South & 136 & $41 \%$ \\
\hline
\end{tabular}

Table 2 shows that $36 \%$ of the SMEs involved in the survey were established for 5 - 10 years, 33\% existed between 11 - 15 years, $17 \%$ were established for more than 15 years and $14 \%$ for less than 5 years. Although the SMEs which are established within less than 5 years are exempted from tax, the current study included them in the analyses, as the study measured perception using self-reporting data and not real data. Moreover, these SMEs will be required to pay tax after 5 years; therefore, it is important to investigate their perception. With regard to the business sector of the SMEs involved in the survey, the results showed that $42 \%$ of them were dealing in retail trade, $28 \%$ were wholesales trade, $13 \%$ were from the service sector, $6 \%$ were in farming, $3 \%$ in industry, $3 \%$ in livestock and $4 \%$ of SMEs were from sectors other than the categories mentioned. Caution is needed to be taken in interpreting the result of some sectors, especially the sectors of less than 30 respondents (Abdul-Jabbar, 2009). Finally, for the purpose of identifying the geopolitical affiliation of the respondents, they were asked to specify their location. The result showed that $59 \%$ of SMEs involved in the survey were located in the North part of Yemen, while $41 \%$ of them were located in the South part of the country. So, it could be said that the questionnaires were distributed fairly between the North and South, as the number of enterprises in the North part are more than in the South part.

According to the demographic information provided by NIS (2012), most employees and business owners in Yemen are males, with a majority of them in urban areas having a secondary level education. The largest numbers 
of business in Yemen fall under the retail trade and whole sales trade (MIT, 2011). Thus, the sample profile fairly reflected the broad characteristics of the Yemeni population.

\section{Descriptive Statistics}

Tax non-compliance was computed through its four situations, specifically, reporting non-compliance, deduction non-compliance, filing non-compliance and payment non-compliance. Also, tax non-compliance was described through its overall value. Table 3 presents the level of the four situations of tax compliance and tax non-compliance of the respondents.

Table 3: Summary of Tax Compliance/Non-Compliance Behaviour by Situations

\begin{tabular}{lcccc}
\hline \multirow{2}{*}{$\begin{array}{c}\text { Tax non-compliance } \\
\text { Situations }\end{array}$} & \multicolumn{2}{c}{ Compliance } & \multicolumn{2}{c}{ Non-compliance } \\
\cline { 2 - 5 } \multicolumn{1}{c}{$\mathbf{N}$} & 175 & $53 \%$ & 155 & $47 \%$ \\
\hline Reporting non-compliance & 175 & $53 \%$ & 155 & $47 \%$ \\
Deduction non-compliance & 108 & $33 \%$ & 222 & $67 \%$ \\
Filing non-compliance & 108 & $33 \%$ & 222 & $67 \%$ \\
Payment non-compliance & & &
\end{tabular}

The table discloses that $53 \%$ of the respondents complied in reporting their taxable income and in claiming the right deduction, while $47 \%$ of SMEs did not. Concerning the level of filing and payment compliance, it represents $33 \%$ of the respondents, whilst $67 \%$ of the respondents did not comply with filing and paying their due tax. With regard to the overall level of tax non-compliance, the respondents were classified into three categories, namely compliant, partly compliant and fully noncompliant, where the compliant respondent is the respondent who complies in the 4 components, while the fully noncompliant is the respondent who is not compliant in the 4 components, and the partly compliant is the respondent who complies in some components and noncompliant in others. Table 4 presents the level of overall tax compliance and tax non-compliance. 
Table 4: Summary of Overall Tax Compliance and Non-Compliance Behaviour

\begin{tabular}{lcccccc}
\hline & \multirow{2}{*}{ Compliance } & \multicolumn{3}{c}{ Non-compliance } \\
\cline { 4 - 7 } & & N & & \multicolumn{2}{c}{$\begin{array}{c}\text { Partly } \\
\text { compliance }\end{array}$} & \multicolumn{2}{c}{$\begin{array}{c}\text { Full non- } \\
\text { compliance }\end{array}$} \\
\cline { 2 - 7 } & $\mathbf{N}$ & N & $\%$ & $\mathbf{N}$ & $\%$ \\
\hline $\begin{array}{l}\text { Overall Tax compliance } \\
\text { and non-compliance }\end{array}$ & 108 & $33 \%$ & 67 & $20 \%$ & 155 & $47 \%$ \\
\hline
\end{tabular}

The table shows three levels of compliance and non-compliance - it presents that only $33 \%$ of the respondents were fully compliant with tax rules and regulations, while $47 \%$ of the respondents were fully non-compliant, whereas $20 \%$ of the respondents were partly compliant with tax laws. Hence, it could be noted that the level of tax non-compliance is high.

Regarding the quality of public governance in Yemen, the viewpoints of respondents were expressed through 17 items (see Appendix 1). Descriptive analysis shows that the mean of all items are less than 2. Also, the table discloses that the lowest mean is the value at 1.37 with a standard deviation of 0.542 , while the highest mean is the value at 1.82 with a standard deviation of 0.807. According to Al-Rabaee (2014), the political changes in Yemen have resulted in instability in the whole country. This situation has reduced the accountability of the people in charge, and hence, the quality of public governance became low. Generally, the overall value of public governance quality result was 1.49 . It gives an impression that taxpayers are not satisfied with the quality of public governance in Yemen. The results of the current study support those reported in literature and reveal a significant dissatisfaction of the people in Yemen about the quality of public governance provided by the government.

\section{Relationship between Public Governance Quality and Tax Non-Compliance}

In order to test the relationship between public governance quality and tax non-compliance behaviour of owners-managers of Yemeni SMEs, the simple regression was carried out (see Appendix 2). The analysis revealed the adjusted $\mathrm{R}^{2}$ is 0.010 , which means that public governance quality was able to explain the $0.10 \%$ of tax non-compliance significantly ( $<<0.036$, $\mathrm{f}=4.448)$. An inverse relationship $(\beta=-0.126 ; \mathrm{p}<0.036)$ was observed 
between public governance quality and tax non-compliance behaviour which showed that tax non-compliance behaviour decreased when public governance quality was higher. The analysis confirmed the findings of previous studies, which evidenced that the positive behaviour by government may be reciprocated by taxpayers through an enhanced compliant behaviour (e.g., Torgler, 2003; Besancon, 2003; Obid, 2008; Rotberg, 2005; 2010; Ross \& McGee, 2011; Alabede, Ariffin, \& Idris, 2011; Alabede, 2012). The Social Exchange Theory explains that relationships between governments and citizens are created by the use of subjective cost and benefit, and evolve on the principle of give and take. Consequently, improving the quality of public governance will be reflected on the perception of people, and in turn, on their compliant behaviour. As a result of the findings in the current empirical study, the Yemeni government must take practical steps to achieve a high quality of public governance to reduce the level of non-compliant behaviour among Yemeni taxpayers.

\section{CONCLUSION}

Public governance quality is considered a sensitive issue and this has led researchers to avoid studying this issue up until the recent past. However, research has been carried out in the current decades to examine the impact of public governance quality on tax non-compliance. The review of literature, has proven that this study is the first study investigating the relationship between public governance quality and tax non-compliance in Yemen. This variable was carefully chosen to meet the environmental, situational and social reality in some developing countries particularly Yemen. Indeed, the regression result supported the Social Exchange Theory and has provided empirical support for the existence of a strong negative relationship between public governance quality and tax non-compliance behaviour among SMEs in Yemen. The study provides practical suggestions for the Yemeni government and all developing countries that in order to enhance a compliant behaviour among taxpayers; the quality of public governance has to be improved. Like any other research work, there are some limitations in the current study. Specifically, the current study investigated the effect of public governance quality as a whole variable, on tax non-compliance. As this variable is a multi-dimensional variable, future research may decompose this variable and test the relationship between each dimension and tax 
compliance behaviour separately, which may provide further details about the possible effects of each dimension on tax non-compliant behaviour.

\section{REFERENCES}

Abdulasiz, A. (2010). The marketing on SMEs in Yemen (Unpublished master thesis). Aden University, Yemen.

Abdul-Jabbar, H., \& Pope, J. (2008). Exploring the relationship between tax compliance costs and compliance issues in Malaysia. Journal of Applied Law and Policy, 1(1), 1-20.

Akpo, U. (2009). The people as government: The importance of tax payment. Akwa Ibom State Revenue Summit. Uyo: Akwa Ibom State Internal Revenue Service.

Alabede, J. O. (2012). An investigation of factors influencing taxpayers compliance behaviour: Evidence from Nigeria (Unpublished doctoral thesis). Universiti Utara Malaysia, Malaysia.

Alabede, J. O., Ariffin, Z. Z., \& Idris, K. (2011). Public governance quality and tax compliance behaviour in Nigeria: The moderating role of financial condition and risk preference. Issues in Social and Environmental Accounting, 5(1/2), 3-24.

Al-Batly, A. (2014). The financial policies of the new Yemeni government. Al-Ahaly. Net, Yemen.

Al-Doais, F. A. (2008). The role of accounting information system in reducing tax evasion in the Republic of Yemen (Unpublished master thesis). University of Al-Albait, Jordan.

Aljaaidi, K. S., Manaf, N. A. A., \& Karlinsky, S. S. (2011). Tax evasion as a crime: A survey of perception in Yemen. International Journal of Business and Management, 6(9), 190-201. 
Almunia, M., \& Lopez-Rodriguez, D. (2018). Under the radar: The effects of monitoring firms on tax compliance. American Economic Journal: Economic Policy, 10(1), 1-38.

Al-Saadi, M. (2014). International cooperation: Vision and mission. AlThawra Gazette (Issued daily by the Yemeni Prime Minister). Issue of 17 July, 2014. Sana'a.

Al-Saqqaf, R. A. (2005). Brand building strategies of SMEs in Yemen: A grounded research that investigates if Yemeni SMEs follow western theory in brand building practices. Dar Al-Feker Al-Mua'aser, Sana'a, Yemen.

Al-Ttaffi, L. H. A., \& Abdul-Jabbar, H. (2020). Geopolitical differences and tax non-compliance among Yemeni SMEs. Journal of Business Management and Accounting, 8(1), 31-45.

Al-Ttaffi, L. H. A. \& Abdul-Jabbar, H. (2015). Does Muslim view on tax influence compliance behaviour?. In International Conference on Accounting Studies (ICAS), Langkawi, Malaysia.

Al-Ttaffi, L. H. A., \& Abdul-Jabbar, H. (2016). Service quality and income tax non-compliance among small and medium enterprises in Yemen. Journal of Advanced Research in Business and Management Studies, 4(1), 12-21.

Al-Ttaffi, L. H. A., Abdul Manaf, N., Aljaidi, K. \& McGee, R. (2011). An investigation of factors influencing tax evasion in Yemen. In The Second Soft Science Conference. November 2011, Vietnam.

Aziz, S. A., \& Al Harethi, A. R. S. (2018). Factors determining tax administration efficiency in Hadhramout, Yemen: Perception from individual taxpayers. The Fifth International Conference on Accounting Studies, Penang, Malaysia.

Besancon, M. (2003). Good governance ranking: The art of measurement. Cambridge: World Peace Foundation. 
Carapico, S. (1998). Civil society in Yemen: The political economy of activism in modern Arabia. Cambridge: Cambridge University Press.

Central Organization of Control \& Audit COCA. (2015). Annual report. Retrieved August 1, 2016, from http://www.arabosai.org

Central Organization of Statistics COS. (2013). Small and Medium Enterprises SMEs. Retrieved August 1, 2016, from http://www.cosit. gov.iq/ar/

Damayanti, T. W., Sutrisno, T., Subekti, I., \& Baridwan, Z. (2015). The role of taxpayer's perception of the government and society to improve tax compliance. Accounting and Finance Research, 4(1), 180-187.

Darby, J., Desbordes, R., \& Wooton, I. (2010). Does public governance always matter? How experience of poor institutional quality influences FDI to the South. CEPR DP, 7533.

Fischer, C. M., Wartick, M., \& Mark, M. (1992). Detection probability and tax compliance: A review of the literature. Journal of Accounting Literature, 11(2), 1-46.

Gubran, M. A. (2009). An analytical study of the reality of tax evasion in Yemen (Fourth edition). Annual Conference on Business and Management. Damascus University, Syria.

Gupta, R., \& McGee, R. W. (2010). A Comparative study of New Zealanders' opinion on the ethics of tax evasion: Students versus Accountants. New Zealand Journal of Taxation Law and Policy, 16(1), 47-84.

Hallsworth, M., List, J. A., Metcalfe, R. D., \& Vlaev, I. (2017). The behavioralist as tax collector: Using natural field experiments to enhance tax compliance. Journal of Public Economics, 148, 14-31.

Helhel, Y., \& Ahmed, Y. (2014). Factors affecting tax attitudes and tax compliance: A survey study in Yemen. European Journal of Business and Management, 6(22), 48-58. 
Huda, M. (2005). SMEs in Yemen (Unpublished master thesis). Sana'a University, Yemen.

Jackson, B. R., \& Milliron, V. C. (1986). Tax compliance research: Finding, problem and prospects. Journal of Accounting Literature, 5(1), 125-165.

Kaufman, K., Kraay, A., \& Mastruzzi, M. (2007). Governance matters VI: Aggregate and individual governance indicators for 1996-2006. Washington D. C.: World Bank Institute, World Bank.

Kirchgässner, G. (2011). Tax morale, tax evasion and the shadow economy. In F. Schneider (Ed.), Handbook on the Shadow Economy (pp. 347-374). Cheltenham: Edward Elgar.

Klepper, S., Mazur, M., \& Nagin, D. (1991). Expert intermediaries and legal compliance: The case of tax preparers. Journal of Law \& Economics, 34(1), 205-229.

Lassen, D. D. (2003). Ethnic division and the size of the informal sector. (EPRU Working Paper Series 2003-01). Retrieved from https://www. econstor.eu/bitstream/10419/82081/1/wp-03-01.pdf

Mas'ud, A., Aliyu, A. A., Gambo, E. M. J., Al-Qudah, A. A., \& Al Sharari, N. (2014). Tax rate and tax compliance in Africa. European Journal of Accounting Auditing and Finance Research, 2(3), 22-30.

McGee, R. W. (1997). The ethics of tax evasion and trade protectionism from an Islamic perspective. Commentaries on Law \& Public Policy, $1(1), 250-262$.

McGee, R. W., Benk, S., Yıldırım, H., \& Kayıkçı, M. (2011). The ethics of tax evasion: A study of Turkish tax practitioner opinion. European Journal of Social Sciences, 18(3), 468-480.

McGee, R. W., Benk, S., Ross, A. M., \& Kılıçaslan, H. (2012). Cheating on taxes if you have a chance: A comparative study of tax evasion opinion in Turkey and Germany. In R. W. McGee (Ed.), The ethics of tax evasion (pp. 357-369). New York, Springer. 
McGee, R. W., Petrides, Y., \& Ross, A. M. (2012). Ethics and tax evasion: A survey of Mexican opinion. In R. W. McGee (Ed.), The ethics of tax evasion (pp. 387-403). New York, Springer.

Ministry of Industry \& Trade (MIT). (2012). Small and Medium Enterprises SMEs. Retrieved June 14, 2015, from http://www.moit.gov.ye

Ministry of Planning \& International Cooperation (MPIC). (2009). Annual Report. Retrieved June 14, 2015, from http://www.yemen.gov.ye

Ministry of Planning \& International Cooperation (MPIC). (2014). Annual Report. Retrieved June 14, 2015, from http://www.yemen.gov.ye

Mohamad, A., Zakaria, M. H., \& Hamid, Z. (2016). Cash economy: Tax evasion amongst SMEs in Malaysia. Journal of Financial Crime, 23(4), 974-986.

Nagel, H., Huber, L. R., Van Praag, M., \& Goslinga, S. (2019). The effect of a tax training program on tax compliance and business outcomes of starting entrepreneurs: Evidence from a field experiment. Journal of Business Venturing, 34(2), 261-283.

National Information System (NIS). (2012). Small and Medium Enterprises SMEs. Retrieved June 14, 2015, from http:/www.yemen-nic.info/ study_guide/index.php

Newman, J. (2005). Participative governance and the remaking of the public. In J. Newman (Eds.), Remaking governance: Peoples, politics and the public sphere. Bristol: Policy Press.

Nwidobie, B. M. (2018). Determinants of voluntary tax compliant behaviours in Nigeria. International Journal of Critical Accounting, 10(1), 59-69.

Obid, S. (2008). Minorities in the Arab World. Albalagh Journal, Yemen, Sana'a, 6(5), 43-46. 
Phillips, M., \& Sandall, R. (2009). Linking business tax reform with governance: How to measure success. Working paper, Investment Climate Department, World Bank Group.

Radzi, N. Z. M., \& Ariffin, Z. Z. (2018). A proposed model of guiltminimization influence towards intention of tax non-compliance among SME owners. International Journal of Accounting, 3(8), 13-21.

Richardson, M., \& Sawyer, A. J. (2001). Taxonomy of the tax compliance literature: Further findings, problems and prospects. Australian Tax Forum, 16(2), 137-284.

Ross, A. M., \& McGee, R. W. (2012). Attitudes toward tax evasion: A demographic study of south African attitudes on tax evasion. Journal of Economics \& Economic Education Research, 13(3), 13-58.

Rotberg, R. (2005). Strengthening governance: Ranking countries would help. The Washington Quarterly, 28(1), 71-81.

Sekaran, U. (2003), Research methods for business: A skill building approach $\left(4^{\text {th }}\right.$ ed.). New Jersey: John Wiley and Sons, Inc.

Sekaran, U., \& Bougie, R. (2010). Research methods for business: A skill building approach. New Jersey: Wiley.

Ser, P. C. (2013). Determinants of tax non-compliance in Malaysia (Unpublished master thesis). Universiti Tunku Abdul Rahman, Petaling Jaya, Malaysia.

Torgler, B. (2003). Tax morale: Theory and analysis of tax compliance (Unpublished doctoral thesis). University of Zurich, Switzerland.

Torgler, B., Schaffner, M., \& Macintyre, A. (2007). Tax compliance, tax morale, and governance quality. International Studies Program Working Paper, Andrew Young School of Policy Studies, Georgia State University.

United Nation. (2007). Public governance indicators: A literature. Washington District of Colombia. 
United Nations Development Program (UNDP). (2005). Program on Governance in the Arab Region. Washington District of Colombia.

World Bank. (2018). Economic Development of Yemen: Sources and Obstacles.

Yemen Times. (2005). Auditing body to fight corruption. As cited in Transparency International's Quarterly Newsletter. Retrieved April 12, 2015, from http://www. transparency.org/content/download/2270/ 14250/version/1/file/ti_q_jun2005.pdf

Yemeni News Agency. (2012). The general budget of 2013. Retrieved May 20, 2015, from http://www.sabanews.net/ar/news262356.htm.

Yong, D., \& Martin, F. (2016). Tax compliance and cultural values: The impact of 'individualism and collectivism on the behaviour of New Zealand small business owners. Available at SSRN: http://ssrn.com/ abstract $=2804417$

Zikmund, W. G. (2003). Business research methods. Oklahoma: SouthWestern. 


\section{APPENDICES}

\section{Appendix 1: Descriptive Statistics of the Items of Public Governance Quality}

\begin{tabular}{|c|c|c|c|c|c|}
\hline Codes & Items & Mean & StdD & Min. & Max. \\
\hline PGQ1 & $\begin{array}{l}\text { I trust the Parliament Council in Yemen is } \\
\text { making good laws for Yemen }\end{array}$ & 1.39 & 0.569 & 1 & 3 \\
\hline PGQ2 & $\begin{array}{l}\text { I believe that there is a free and fair election } \\
\text { in Yemen }\end{array}$ & 1.43 & 0.621 & 1 & 4 \\
\hline PGQ3 & $\begin{array}{l}\text { I believe that there is no wastefulness in } \\
\text { government expenditure in Yemen }\end{array}$ & 1.43 & 0.601 & 1 & 3 \\
\hline PGQ4 & $\begin{array}{l}\text { I have access to the published accounts and } \\
\text { annual report of the government in Yemen }\end{array}$ & 1.57 & 0.612 & 1 & 3 \\
\hline PGQ5 & $\begin{array}{l}\text { I believe that political stability is improving in } \\
\text { Yemen }\end{array}$ & 1.42 & 0.610 & 1 & 4 \\
\hline PGQ6 & $\begin{array}{l}\text { I believe that political protest is not a threat to } \\
\text { Yemeni stability }\end{array}$ & 1.37 & 0.542 & 1 & 3 \\
\hline PGQ7 & $\begin{array}{l}\text { I believe that territorial and sectarian conflict is } \\
\text { not a threat to stability in Yemen }\end{array}$ & 1.42 & 0.619 & 1 & 4 \\
\hline PGQ8 & $\begin{array}{l}\text { I am satisfied with quality of general } \\
\text { infrastructure in Yemen }\end{array}$ & 1.42 & 0.590 & 1 & 3 \\
\hline PGQ9 & $\begin{array}{l}\text { I feel that Yemeni public servants are not } \\
\text { vulnerable to political interference in Yemen }\end{array}$ & 1.64 & 0.648 & 1 & 3 \\
\hline PGQ10 & $\begin{array}{l}\text { I am satisfied with the manner the government } \\
\text { is handling the health service in Yemen }\end{array}$ & 1.59 & 0.657 & 1 & 4 \\
\hline PGQ11 & $\begin{array}{l}\text { I am satisfied with the manner the government } \\
\text { is handling the education system in Yemen }\end{array}$ & 1.47 & 0.629 & 1 & 4 \\
\hline PGQ12 & $\begin{array}{l}\text { I feel that Yemeni Judiciary is free from the } \\
\text { interference of other agencies of government }\end{array}$ & 1.45 & 0.623 & 1 & 4 \\
\hline PGQ13 & $\begin{array}{l}\text { I believe that justice is fairly administered in } \\
\text { Yemen }\end{array}$ & 1.56 & 0.592 & 1 & 3 \\
\hline PGQ14 & $\begin{array}{l}\text { I believe that Yemeni government has an } \\
\text { effective power in combating crime }\end{array}$ & 1.41 & 0.608 & 1 & 4 \\
\hline PGQ15 & I trust the financial honesty of Yemeni politicians & 1.41 & 0.599 & 1 & 4 \\
\hline PGQ16 & $\begin{array}{l}\text { I believe that the diversion of public funds due } \\
\text { to corruption is not common in Yemen }\end{array}$ & 1.58 & 0.639 & 1 & 4 \\
\hline \multirow[t]{2}{*}{ PGQ17 } & $\begin{array}{l}\text { I think that individual and firms, frequently, make } \\
\text { extra payments in connection to tax payment, } \\
\text { loan application, securing contract etc. }\end{array}$ & 1.82 & 0.807 & 1 & 4 \\
\hline & Overall & 1.49 & 0.466 & & \\
\hline
\end{tabular}

$\mathrm{StdD}=$ standard deviation, Min = minimum, Max= maximum 


\section{Appendix 2: Regression Analysis (SPSS Outputs)}

\begin{tabular}{|c|c|c|c|c|}
\multicolumn{7}{|c|}{ Model Summary } \\
\hline Model & $\mathbf{R}$ & R Square & $\begin{array}{c}\text { Adjusted R } \\
\text { Square }\end{array}$ & $\begin{array}{c}\text { Std. Error of the } \\
\text { Estimate }\end{array}$ \\
\hline 1 & $.116^{\mathrm{a}}$ & .013 & .010 & .49550 \\
\hline
\end{tabular}

Predictors: (Constant), PGQ

\section{ANOVA $^{a}$}

\begin{tabular}{|l|l|c|c|c|c|c|}
\hline \multicolumn{2}{|c|}{ Model } & $\begin{array}{c}\text { Sum of } \\
\text { Squares }\end{array}$ & df & $\begin{array}{c}\text { Mean } \\
\text { Square }\end{array}$ & F & Sig. \\
\hline \multirow{3}{*}{1} & Regression & 1.092 & 1 & 1.092 & 4.448 & $.036^{\text {b }}$ \\
& Residual & 80.532 & 328 & .246 & & \\
& Total & 81.624 & 329 & & & \\
\hline
\end{tabular}

a. Dependent Variable: TNC

b. Predictors: (Constant), PGQ

\section{Coefficients $^{\mathrm{a}}$}

\begin{tabular}{|c|c|c|c|c|c|c|}
\hline \multirow{2}{*}{ Model } & \multicolumn{2}{|c|}{$\begin{array}{c}\text { Unstandardized } \\
\text { Coefficients }\end{array}$} & $\begin{array}{c}\text { Standardized } \\
\text { Coefficients }\end{array}$ & \multirow{2}{*}{ t } & \multirow{2}{*}{ Sig. } \\
\cline { 3 - 5 } \multicolumn{2}{|c|}{1} & B & Std. Error & Beta & & \\
\hline \multirow{2}{*}{1} & (Constant) & 1.635 & .093 & & 17.635 & .000 \\
& PGQ & -.126 & .060 & -.116 & -2.109 & .036 \\
\hline
\end{tabular}

a. Dependent Variable: TNC 